\title{
Upaya Meningkatkan Hasil Belajar Peserta Didik pada Mata Pelajaran Akidah Akhlak melalui Metode Lectures Vary
}

\author{
Fitri Fatimatuzahroh \\ Institut Agama Islam Darussalam (IAID) Ciamis, Jawa Barat. \\ Email: fitrifatimatuzahroh1994@gmail.com \\ Lilis Nurteti \\ Institut Agama Islam Darussalam (IAID) Ciamis, Jawa Barat. \\ Email: lilis_nurteti_iaid@yahoo.co.id \\ S. Koswara \\ Program Pascasarjana, Institut Agama Islam Darussalam (IAID) Ciamis, Jawa Barat. \\ Email: koswara.iaid@gmail.com \\ Received: November 11, 2018 | Accepted: April 20, 2019
}

\begin{abstract}
This study aims to discuss learning planning, learning implementation, and student learning outcomes of Akidah Akhlak subject, specifically material about "avoiding despicable morals" using the "lectures vary" method in class V MI Kiarapayung Ciamis. The method used is the Kurt Lewin model of classroom action research (CAR). While the data collection techniques used were observation, tests, interviews, documentation and data were analyzed descriptively. After conducting research in class V MI Kiarapayung, Rancah Subdistrict, Ciamis District, the learning outcomes of students using the "lectary vary" learning method have increased, namely an average pre-cycle of 72.8 with completeness of $44 \%$, cycle I an average of 81.6 with completeness $72 \%$, cycle II averaged 96 with completeness $96 \%$, and cycle III averaged 96.8 with $100 \%$ completeness. Thus, the "lectures vary" learning method can improve student learning outcomes.
\end{abstract}

\begin{abstract}
Abstrak
Penelitian ini bertujuan untuk membahas perencanaan pembelajaran, pelaksanaan pembelajaran, dan hasil belajar siswa mata pelajaran Aqidah Akhlak pokok bahasan "menghindari akhlak tercela" menggunakan metode lectures vary di kelas V MI Kiarapayung Ciamis. Metode yang digunakan adalah metode penelitian tindakan kelas (PTK) model Kurt Lewin. Sedangkan teknik pengumpulan data yang digunakan adalah observasi, tes, wawancara, dokumentasi dan data dianalisis secara deskriptif. Setelah dilakukan penelitian di kelas V MI Kiarapayung Kecamatan Rancah Kabupaten Ciamis, hasil belajar peserta didik dengan
\end{abstract}


menggunakan metode pembelajaran Lectues Vary mengalami peningkatan, yaitu pra siklus ratarata 72,8 dengan ketuntasan $44 \%$, siklus I rata-rata 81,6 dengan ketuntasan $72 \%$, siklus II rata-rata 96 dengan ketuntasan $96 \%$, dan siklus III rata-rata 96,8 dengan ketuntasan $100 \%$. Dengan demikian, metode pembelajaran Lectures Vary dapat meningkatkan hasil belajar siswa.

\section{Keywords}

Islamic education, lectures vary method, learning outcomes.

\section{Pendahuluan}

Undang-undang RI nomor 20 tahun 2003 pasal 3 menjelaskan bahwa "Pendidikan nasional berfungsi mengembangkan kemampuan dan membentuk watak serta peradaban bangsa yang bermartabat dalam rangka mencerdaskan bangsa, bertujuan untuk berkembangnya potensi peserta didik agar menjadi manusia beriman dan bertakwa kepada Tuhan Yang Maha Esa, berakhlak mulia, sehat, berilmu, cakap, kreatif, mandiri, dan menjadi warga negara yang demokratis serta bertanggung jawab" (Wardati, 2011, p. 129).

Peserta didik Sekolah Dasar (SD) umurnya berkisar antara 6 atau 7 tahun, sampai 12 atau 13 tahun. Menurut Piaget, mereka berada pada fase operasional konkret. Kemampuan yang tampak pada fase ini adalah kemampuan dalam proses berpikir untuk mengoperasikan kaidah-kaidah logika, meskipun masih terikat dengan objek yang bersifat konkret. Dari usia perkembangan kognitif, Peserta didik SD masih terikat dengan objek konkret yang dapat ditangkap oleh panca indera. Dalam pembelajaran Aqidah akhlak, Peserta didik memerlukan alat bantu berupa media, dan alat peraga yang dapat memperjelas apa yang akan disampaikan oleh guru sehingga lebih cepat dipahami dan dimengerti oleh Peserta didik. Proses pembelajaran pada fase konkret dapat melalui tahapan konkret, semi konkret, semi abstrak, dan selanjutnya abstrak (Heruman, 2010, pp. 1-2).

Dalam Aqidah akhlak, menurut Nurhayati aqidah akhlak bagi peserta didik SD/MI berguna agar peserta didik diarahkan untuk mencapai keseimbangan antara kemajuan lahiriah dan batiniah, keselarasan hubungan antara manusia dalam lingkup sosial masyarakat dan lingkungannya juga hubungan manusia dengan Tuhannya. Dan dengan pendidikan Aqidah Akhlak pula peserta didik akan memiliki derajat yang tinggi yang melebihi makhluk lainnya (Nurhayati, 2014, p. 290) .

Pelajaran Aqidah akhlak sering dianggap pelajaran yang sulit bagi para peserta didik, khususnya peserta didik yang masih berusia dini di MI Kiarapayung Kecamatan Rancah Kabupaten Ciamis, hal ini karena kebanyakan 
pendidik dalam proses pembelajaran kurang tepat menggunakan metode, tekhnik, dan media-media yang mampu menunjang untuk membuat suasana belajar menjadi mudah dan menyenangkan bagi peserta didik dan yang akan mampu meningkatkan keterampilan menggunakan berbagai konsep aqidah akhlak dalam kehidupan sehari-hari peserta didik (Hasil pengamatan di kelas V MI Kiarapayung Kecamatan Rancah Kabupaten Ciamis, tanggal 12 Maret 2018).

Hasil belajar Peserta didik pada mata pelajaran aqidah akhlak kelas V MI Kiarapayung Kecamatan Rancah Kabupaten Ciamis relatif belum mampu mencapai Kriteria Ketuntasan Minimal (KKM) sebesar 75. Setelah dilakukan tes yaitu hanya 11 orang dari jumlah 25 Peserta didik, atau dengan rata-rata masih 44\% Peserta didik yang sudah mampu mencapai nilai KKM dan 56\% lagi Peserta didik yang belum mampu mencapai nilai KKM (wawancara dengan Ibu Iyah Sadiyah guru kelas V). Merujuk pada berbagai pendapat para ahli aqidah akhlak MI dalam mengembangkan kreativitas dan kompetensi Peserta didik, maka guru hendaknya dapat menyajikan pembelajaran yang efektif dan efisien, sesuai dengan kurikulum dan pola pikir Peserta didik. Dalam mengajarkan aqidah akhlak, guru harus memahami bahwa kemampuan setiap Peserta didik berbeda-beda, serta tidak semua Peserta didik menyenangi mata pelajaran aqidah akhlak.

Mata pelajaran Aqidah Akhlak bertujuan untuk menumbuhkan pola tingkah laku peserta didik yang bulat melalui latihan kejiwaan, kecerdasan, penalaran, perasaan dan indera. Pendidikan Aqidah Akhlak dengan tujuan semacam itu harus melayani pertumbuhan peserta didik dalam segala aspeknya, baik aspek spiritual, intelektual, imajinasi, jasmaniah, ilmiah maupun bahasa. Pendidikan Aqidah Akhlak harus mendorong semua aspek tersebut kearah keutamaan serta pencapaian kesempurnaan hidup berdasarkan nilai-nilai Islam. Hal ini sesuai dengan firman Allah: "Dan sesungguhnya Engkau (Muhammad) benar-benar berbudi pekerti yang agung". (Q.S. Al-Qalam 68:4)

Setelah melalui proses belajar maka Peserta didik diharapkan dapat mencapai tujuan belajar yang disebut juga sebagai hasil belajar yaitu kemampuan yang dimiliki Peserta didik setelah menjalani proses belajar. Sudjana berpendapat, hasil belajar adalah kemampuan-kemampuan yang dimiliki Peserta didik setelah ia menerima pengalaman belajarnya (Sudjana, 2004, p. 17). Tujuan belajar adalah sejumlah hasil belajar yang menunjukan bahwa Peserta didik telah melakukan perbuatan belajar, yang umumnya meliputi pengetahuan, keterampilan dan sikap-sikap yang baru, yang diharapkan dapat dicapai oleh Peserta didik (Jihad \& Haris, 2013, p. 15).

Untuk dapat mencapai suatu tujuan pembelajaran maka sebaiknya pendidik harus mampu menggunakan suatu metode pembelajaran. 
Penggunaan metode dalam pembelajaran sangat penting dalam penyampaian materi kepada peserta didik apalagi peserta didik yang masih duduk di Sekolah Dasar yang sangat memerlukan arahan dan bimbingan. Metode dalam pembelajaran mempunyai peran penting dalam penyampaian materi pada proses pembelajaran.

Metode adalah salah satu alat untuk mencapai tujuan pembelajaran. Metode adalah pelicin jalan pengajaran menuju tujuan/ sasaran. Jadi, guru sebaiknya menggunakan metode yang dapat menunjang kegiatan belajar mengajar, sehingga dapat dijadikan sebagai alat yang efisien untuk mencapai tujuan (Mufarokah, 2009, p. 80). Salah satu metode yang dapat dimanfaatkan oleh pendidik dalam proses pembelajaran khususnya pelajaran aqidah akhlak dapat menggunakan metode lectures vary. Menurut W. Gulo, metode Lectures Vary terdiri dari dua kata, yaitu Lectures dan Vary. Lectures adalah ceramah. Ceramah dapat diartikan sebagai cara menyajikan pelajaran melalui penuturan lisan atau penjelasan langsung kepada sekelompok peserta didik. Adapun Vary artinya variasi (Gulo, 2002, p. 29).

Berdasarkan beberapa pendapat di atas, dapat disimpulkan bahwa metode pembelajaran lectures vary adalah penggabungan antara metode ceramah, tanya jawab, penugasan dan yang lainnya, penggunaannya harus didukung dengan alat dan media atau dengan metode lainnya yang dapat menciptakan interaksi belajar-mengajar yang dinamis dan bervariasi (Gulo, 2002, p. 30). Dengan demikian, masalah pokok dalam penelitian ini, yaitu: Bagaimana upaya meningkatkan hasil belajar peserta didik dengan menggunakan metode lectures vary pada mata pelajaran Aqidah Akhlak pokok bahasan 'menghindari akhlak tercela' pada peserta didik kelas V MI Kiarapayung Kecamatan Rancah Kabupaten Ciamis.

Menurut Mahmud Yunus secara bahasa Aqidah berasal dari kata 'aqoda, ya'qidu, 'aqdan, 'itiqoodan yaitu: kepercayaan hati atau keyakinan (Yunus, 1973, p. 275). Sementara pengertian aqidah secara terminologi atau istilah dikemukakan oleh para ahli di antaranya:

Menurut Imam Al-Ghazali menyatakan apabila aqidah telah tumbuh pada jiwa seorang muslim, maka tertanamlah dalam jiwanya rasa bahwa Allah sajalah yang paling berkuasa, segala wujud yang ada ini hanyalah makhluk belaka (Al-Ghazali, 1970, p. 17). Menurut Abdullah Azzam aqidah adalah iman dengan semua rukun-rukunnya yang enam. Maksudnya adalah pengertian iman yaitu: keyakinan atau kepercayaan akan adanya Allah SWT, Malaikat-malaikatNya, Kitab-kitabNya, Nabi-nabiNya, hari kebangkitan dan qadha dan qadhar-Nya (Azzam, 1993, p. 17). Dari dua pengertian di atas dapat disimpulkan bahwa Aqidah adalah dasar-dasar pokok kepercayaan atau keyakinan hati seorang muslim yang bersumber dari ajaran Islam yang wajib 
dianut oleh setiap muslim sebagai sumber keyakinan yang mengikat dan mendasar.

Adapun akhlak secara etimologi berasal dari bahasa arab jama' dari bentuk mufradnya khuluqun yang menurut bahasa diartikan: pekerti, perangai, tingkah laku atau tabiat. Makna akhlak dalam Alquran adalah bentuk tunggal, yaitu khuluk tercantum dalam surat Al-Qalam, sebagai berikut:

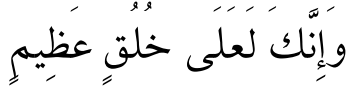

Dan sesungguhnya Engkau (Muhammad) benar-benar berbudi pekerti yang agung.

(Q.S. Al-Qalam 68:4)

Menurut Abdul Halim kata akhlak merupakan kata yang seringkali terdengar dalam kehidupan sehari-hari. Begitu kita mendengar kata ini sehingga seolah-olah kita tahu pengertian ini dengan jelas, padahal jika ditanyakan apa itu akhlak, kita biasanya terdiam memikirkan jawabannya (Halim, 2000, p. 23). Pengertian Akhlak dapat ditinjau dari dua pengertian secara etimologis dan terminologis. Secara etimologis, kata akhlak berasal dari bahasa arab al-Akhlak, kata ini merupakan bentuk jamak dari al-khuluk yang berarti budi pekerti, tabiat atau watak. Hal ini sesuai dengan firman Allah: Dan janganlah kamu memalingkan mukamu dari manusia (karena sombong) dan janganlah kamu berjalan di muka bumi dengan angkuh. Sesungguhnya Allah tidak menyukai orang orang yang sombong lagi membanggakan diri. (Q.S. Luqman 31:18). Nabi juga menegaskan "menimpa kepadamu suatu penyakit umat-umat sebelum kamu yaitu benci membenci dan dengki. Dialah pencukur agama, bukan sekedar pencukur rambut." (H.R. Thabrani)

Adapun pengertian akhlak secara terminologis telah banyak dikemukakan oleh para ahli, salah satunya adalah pengertian akhlak sebagaimana diungkapkan oleh Ahmad Amin. Menurut Amin, akhlak adalah kehendak yang dibiasakan, dalam pengertian jika kehendak itu membiasakan sesuatu maka kebiasaan itu dinamakan akhlak (Amin, 1993, p. 62). Dari penjabaran di atas dapat disimpulkan bahwa makna Aqidah Akhlak adalah ikatan dari suatu sistem keyakinan yang diyakini kebenarannya, yang tertanam dalam hati, ucapan dengan lisan dan diamalkan dengan perbuatan yang terpuji sesuai dengan ajaran Alquran dan Hadits.

Mata pelajaran Aqidah Akhlak di Madrasah Ibtidaiyah berisi pelajaran yang dapat mengarahkan kepada pencapaian kemampuan dasar peserta didik untuk bisa memahami rukun iman dengan sederhana serta pengalaman dan pembiasaan berakhlak Islami secara sederhana pula, untuk dapat dijadikan perilaku dalam kehidupan sehari-hari serta sebagai bekal untuk jenjang pendidikan berikutnya. Ruang lingkup pembelajaran Aqidah Akhlak di Madrasah Ibtidaiyah meliputi; 1) aspek aqidah (keimanan); 2) aspek akhlak; 3) aspek adab Islami; 4) aspek kisah teladan. 
Adapun tujuan pembelajaran aqidah akhlak adalah sasaran yang hendak dicapai setelah kegiatan selesai. Adapun tujuan pembelajaran Aqidah Akhlak dapat dilihat dari beberapa perspektif di antaranya sebagai berikut: tujuan pembelajaran aqidah akhlak secara umum dan tujuan pembelajaran aqidah akhlak secara khusus. Aqidah Akhlak merupakan salah satu bidang studi dalam pendidikan agama Islam. Maka tujuan umum pendidikan Aqidah Akhlak sesuai dengan tujuan umum pendidikan agama Islam. Menurut Abdurrahman Saleh Abdullah dalam (Mahmud, 2011, p. 23) tujuan umum pendidikan agama Islam adalah membentuk kepribadian sebagai khalifah Allah atau sekurang-kurangnya mempersiapkan peserta didik ke jalan yang mengacu pada tujuan akhir manusia. Tujuan utama khalifah Allah adalah beriman kepada Allah dan tunduk patuh secara total kepada-Nya. Hal ini sesuai dengan firman Allah yang berbunyi:

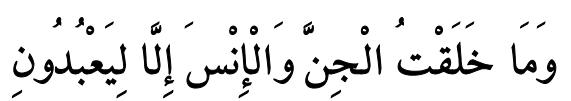

Dan aku tidak menciptakan jin dan manusia melainkan supaya mereka mengabdi kepada-Ku. (Q.S Adz-Dzariyat: 56).

Selain tujuan umum di atas, pembelajaran aqidah akhlak memiliki tujuan khusus. Tujuan khusus pembelajaran Aqidah Akhlak adalah sebagai berikut; a) untuk menumbuhkan dan meningkatkan keimanan peserta didik; b) menghindarkan manusia dari kemusyrikan; c) membimbing akal pikiran agar tidak tersesat. Dengan demikian tujuan pendidikan Aqidah Akhlak tidak hanya sekedar mengikuti atau mengisi otak anak-anak dengan ilmu pengetahuan (teori) belaka, justru lebih mendalam lagi mendidik psikis, kesehatan, mental, perasaan dan praktis serta mendidik psikis sekaligus mempersiapkan anak-anak menjadi anggota masyarakat. Memberikan kemampuan dan keterampilan dasar kepada peserta didik untuk meningkatkan pengetahuan, pemahaman, penghayatan dan pengalaman Akhlak Islami dan nilai-nilai keteladanan dalam kehidupan sehari-hari.

Setelah membahas tentang aqidah akhlak selanjutnya akan dibahas secara teoretis penjelasan mengenai metode lectures vary. Menurut W. Gulo metode lectures vary terdiri dari dua kata, yaitu lectures dan vary. Lectures adalah ceramah. Ceramah dapat diartikan sebagai cara menyajikan pelajaran melalui penuturan lisan atau penjelasan langsung kepada sekelompok peserta didik. Adapun vary artinya variasi. Metode lectures vary merupakan penggabungan antara metode ceramah, tanya jawab, penugasan dan yang lainnya, penggunaannya harus didukung dengan alat dan media atau dengan metode lainnya yang dapat menciptakan interaksi belajar-mengajar yang dinamis dan bervariasi (Gulo, 2002, pp. 29-30).

Menurut W. Gulo disebut lectures vary karena dalam strategi ini terdapat beberapa komponen yaitu; 1) variasi metode ceramah; 2) variasi media alat 
indera; 3) variasi penampilan; 4) variasi bahan sajian (Gulo, 2002, p. 29). Adapun kelebihan dan kekurangan metode lectures vary menurut Hisyam Zaini sebagai berikut. Kelebihan metode lectures vary; 1) praktis dari sisi persiapan dan media yang digunakan; 2) efisiensi dari sisi waktu dan biaya; 3) dapat menyampaikan materi yang banyak; 4) mendorong guru atau dosen menguasai materi; 5) lebih mudah mengontrol kelas; 6) peserta didik tidak perlu persiapan; 7) peserta didik dapat langsung menerima ilmu pengetahuan. Sedangkan kekurangan metode pembelajaran lectures vary yaitu sebagai berikut; 1) membosankan; 2) informasi hanya satu arah; 3) menggurui dan melelahkan; 4) kurang terkendali baik waktu maupun materi (Hisyam \& dkk., 2008, p. 93).

Selain kelebihan dan kekurangan metode lecture vary berikut langkahlangkah penggunaan metode Lectures Vary. Pertama, pendahuluan atau apersepsi; kedua, penjelasan atau menyajikan materi. Langkah penyajian adalah langkah penyampaian materi pelajaran sesuai dengan persiapan yang telah dilakukan. Yang harus dipikirkan guru dalam penyajian ini adalah bagaimana agar materi pelajaran dapat dengan mudah ditangkap dan dipahami oleh peserta didik. Karena itu ada beberapa hal yang harus diperhatikan dalam pelaksanaan langkah ini, yaitu sebagai berikut; a) penggunaan bahasa; b) intonasi suara; c) menjaga kontak mata dengan peserta didik; d) menggunakan variasi yang menyenangkan (Hisyam \& dkk., 2008, pp. 107-112).

Hasil belajar adalah kemampuan yang diperoleh anak setelah melalui kegiatan belajar. Belajar itu sendiri merupakan suatu proses dari seseorang yang berusaha untuk memperoleh suatu bentuk perubahan perilaku yang relatif menetap. Dalam kegiatan pembelajaran atau kegiatan intruksional, biasanya guru menetapkan tujuan belajar. Peserta didik yang berhasil dalam belajar adalah yang berhasil mencapai tujuan-tujuan pembelajaran atau tujuan intruksional (Jihad \& Haris, 2013, p. 14).

Menurut Benjamin S. Bloom dalam (Winkel, 1987, p. 149) tiga ranah (domain) hasil belajar, yaitu kognitif, afektif dan psikomotorik. Sementara menurut A.J. Romizowski seperti dikutip Jihad dan Haris, hasil belajar merupakan keluaran (outputs) dari suatu sistem pemrosesan masukan (input). Masukan dari sistem tersebut berupa bermacam-macam informasi sedangkan keluarannya adalah perbuatan atau kinerja (performance) (Jihad \& Haris, 2013, p. 14). Dapat kita simpulkan bahwa hasil belajar merupakan pencapaian bentuk perubahan perilaku yang cenderung menetap meliputi ranah kognitif, afektif dan psikomotorik. Perubahan tersebut terjadi setelah proses belajar yang dilakukan dalam waktu tertentu.

Benjamin S. Bloom dalam (Jihad \& Haris, 2013, pp. 14-15) berpendapat bahwa hasil belajar dapat dikelompokkan ke dalam dua macam 
yaitu pengetahuan dan keterampilan. Pengetahuan terdiri dari empat kategori, yaitu: 1) Pengetahuan tentang fakta, 2) Pengetahuan tentang prosedural, 3) Pengetahuan tentang konsep, 4) Pengetahuan tentang prinsip. Keterampilan juga terdiri dari empat kategori, yaitu: 1) Keterampilan untuk berpikir atau keterampilan kognitif, 2) Keterampilan untuk bertindak atau keterampilan motorik, 3) Keterampilan bereaksi atau bersikap, 4) Keterampilan berinteraksi.

Untuk memperoleh hasil belajar, dilakukan evaluasi atau penilaian yang merupakan tindak lanjut atau cara untuk mengukur tingkat penguasaan Peserta didik. Kemajuan prestasi belajar Peserta didik tidak saja diukur dari tingkat penguasaan ilmu pengetahuan tetapi juga sikap dan keterampilan. Dengan demikian penilaian hasil belajar Peserta didik mencakup segala hal yang dipelajari di sekolah, baik itu menyangkut pengetahuan, sikap, dan keterampilan (Jihad \& Haris, 2013, pp. 14-15). Adapun penilaian dalam proses pembelajaran meliputi: 1) evaluasi formatif, 2) evaluasi sumatif, 3) pelaporan hasil penilaian, 4) pelaksanaan program perbaikan atau pengayaan (Suryosubroto, 2002, p. 53).

Berdasarkan pendapat di atas dapat dijelaskan sebagai berikut: 1) evaluasi formatif adalah penilaian yang dilakukan guru setelah satu pokok bahasan selesai dipelajari oleh Peserta didik. Penilaian formatif disebutkan dengan istilah penilaian pada akhir satu pelajaran. Penilaian ini berfungsi untuk mengetahui sejauh mana ketercapaian tujuan intruksional khusus yang telah ditentukan dalam standar kompetensi; 2) evaluasi sumatif adalah penilaian yang diselenggarakan oleh guru setelah satu jangka waktu tertentu. Penilaian sumatif berguna untuk memperoleh informasi tentang keberhasilan belajar Peserta didik yang dipakai sebagai masukan utama untuk menentukan nilai lapor atau nilai akhir semester; 3) pelaporan hasil penilaian. Setelah memberikan evaluasi formatif maupun sumatif, setiap tengah semester atau akhir semester guru harus mengolah nilai akhir dan memasukan dalam buku lapor, yang merupakan laporan hasil kerja. Buku lapor berfungsi untuk laporan hasil kerja sekolah kepada orang tua atau wali murid; 4) pelaksanaan program perbaikan dan pengayaan. Apabila seorang peserta didik dalam ulangan (tes formatif atau tes sumatif) mencapai nilai kurang dari 6,00 atau daya serapnya kurang dari $60 \%$ maka yang bersangkutan harus mengikuti perbaikan. Tujuan ulangan perbaikan adalah agar Peserta didik memperoleh penguasaan yang baik terhadap tujuan pembelajaran yang harus dicapai, dengan menjelaskan materi yang sedang dipelajari atau memberikan tugas tambahan kepada Peserta didik yaitu mengerjakan kembali soal. Bagi Peserta didik yang sudah mencapai standar kompetensi, sekurang-kurangnya 60\% dapat diberikan pengayaan, apabila masih ada waktu untuk satu pelajaran tertentu sebelum beralih kepada materi lain. 
Kehadiran faktor-faktor psikologis dalam belajar akan memberikan andil yang cukup penting. Faktor-faktor psikologis akan senantiasa memberikan landasan dan kemudahan dalam upaya mencapai tujan belajar secara optimal. Sebaliknya, tanpa kehadiran faktor-faktor psikologis, bisa jadi memperlambat proses belajar, bahkan dapat pula menambah kesulitan dalam belajar (Djamarah, 2008, p. 58). Faktor psikologis pada umumnya meliputi kemampuan, motivasi (motif) belajar, minat dan perhatian, sikap dan kebiasaan, bakat khusus dan kesiapan belajar, sedangkan faktor fisiologis adalah kondisi fisik Peserta didik itu sendiri.

Metode adalah cara yang digunakan guru untuk mengimplementasikan rencana pembelajaran yang sudah disusun dalam kegiatan nyata agar tujuan yang diinginkan tercapai secara optimal. Ini berarti metode digunakan untuk merealisasikan strategi yang telah ditetapkan sehingga dapat dikatakan bahwa metode dalam rangkaian sistem pembelajaran memegang peranan yang sangat penting. Hal ini sesuai dengan pendapat Sanjaya yang menyatakan bahwa keberhasilan implementasi strategi pembelajaran sangat tergantung pada cara guru menggunakan metode pembelajaran, karena suatu strategi pembelajaran hanya mungkin dapat diimplementasikan melalui penggunaan metode pembelajaran (Sina, 2011, p. 6).

Metode yang dilakukan guru dapat mengakibatkan penyajian bahwa pelajaran lebih menarik perhatian Peserta didik, mudah diterima atau dipahami Peserta didik dan kelaspun akan menjadi lebih hidup. Dengan demikian, jelas bahwa penggunaan metode sangat mempengaruhi proses belajar mengajar di kelas sehingga dapat meningkatkan perkembangan hasil belajar Peserta didik. Maka dapat disimpulkan bahwa faktor-faktor yang mempengaruhi hasil belajar salah satunya yaitu penggunaan metode dalam pembelajaran, dengan menggunakan metode pembelajaran dapat membangkitkan keinginan dan minat yang baru, membangkitkan motivasi dan rangsangan kegiatan belajar, membawa pengaruh-pengaruh psikologis terhadap Peserta didik, dan akhirnya akan membuahkan hasil belajar yang baik. Adapun faktor luar yang mempengaruhi terhadap proses dan hasil belajar meliputi faktor lingkungan, lingkungan sosial dan lingkungan alam. Kemudian juga faktor instrumen yang meliputi bahan pengajaran termasuk kurikulum, guruatau pengajar, media dan teknik mengajar, sarana dan fasilitas belajar.

\section{Metode Penelitian}

Metode penelitian yang digunakan adalah metode penelitian tindakan kelas (PTK) model Kurt Lewin (Suyoto, 2016, p. 378). Sedangkan teknik pengumpulan data yang digunakan adalah observasi, tes, wawancara, 
dokumentasi dan data dianalisis secara deskriptif (Wiraatmaja, 2008, p. 21). Penelitian ini bertujuan untuk meningkatkan hasil belajar Peserta didik dengan menggunakan metode lectures vary pada mata pelajaran Aqidah Akhlak pokok bahasan Menghindari Akhlak Tercela. Penelitian Tindakan Kelas pada Peserta didik kelas V MI Kiarapayung Kecamatan Rancah Kabupaten Ciamis.

\section{Hasil Penelitian dan Pembahasan}

Penyusunan perencanaan pembelajaran aqidah akhlak pokok bahasan menghindari akhlak tercela kelas V MI Kiarapayung Kecamatan Rancah Kabupaten Ciamis dengan mengunakan metode pembelajaran lectures vary terlihat meningkat dari siklus ke siklus. Hal ini dapat dilihat dari dari hasil observasi pada siklus I mencapai nilai rata-rata 90,65 siklus II mencapai nilai 90,69 dan siklus III mencapai nilai 91,23. Hal ini menunjukkan bahwa guru mengalami peningkatan kemampuan dalam penyusunan perencanaan pembelajaran. Sehingga dengan demikian dapat disimpulkan bahwa dengan menggunakan metode pembelajaran lectures vary pada mata pelajaran aqidah akhlak pokok bahasan menghindari akhlak tercela di kelas V MI Kiarapayung Kecamatan Rancah Kabupaten Ciamis terbukti dapat meningkatkan kemampuan guru dalam penyusunan perencanaan pembelajaran.

Pelaksanaan pembelajaran aqidah akhlak pokok bahasan menghindari akhlak tercela di kelas V MI Kiarapayung Kecamatan Rancah Kabupaten Ciamis dengan menggunakan metode pembelajaran lectures vary yang dilakukan oleh guru telah menunjukkan kegiatan pembelajaran yang mengacu kepada diskusi aktif, inovatif, kreatif, efektif, dan menyenangkan. Kemampuan guru dalam melaksanakan pembelajaran terlihat meningkat dari siklus kesiklus. Hal ini dapat dilihat dari hasil observasi pada siklus I mencapai nilai rata-rata 89,81 siklus II mencapai nilai 90,22 dan siklus III mencapai nilai 91,16. Sehingga dengan demikian dapat disimpulkan bahwa dengan menggunakan metode pembelajaran lectures vary pada mata pelajaran aqidah akhlak pokok bahasan Menghindari Akhlak Tercela di kelas V MI Kiarapayung Kecamatan Rancah Kabupaten Ciamis terbukti dapat meningkatkan kemampuan guru dalam melaksanakan pembelajaran.

Hasil belajar Peserta didik kelas V MI Kiarapayung Kecamatan Rancah Kabupaten Ciamis setelah mengikuti pembelajaran aqidah akhlak pokok bahasan Menghindari Akhlak Tercela dengan menggunakan metode pembelajaran lectures vary mengalami peningkatan. Hal ini dapat dilihat dari hasil siklus I dengan nilai rata-rata 81,6 dengan presentase ketuntasan $72 \%$ pada perhitungan 7 orang yang belum tuntas dan 18 orang yang sudah tuntas dari nilai KKM yang telah ditentukan, siklus II dengan nilai rata-rata 96 
dengan presentase ketuntasan $96 \%$ pada perhitungan 1 orang yang belum tuntas dan 24 orang yang sudah tuntas dari nilai KKM yang telah ditentukan, dan siklus III dengan nilai rata-rata 96,8 dengan presentase ketuntasan $100 \%$ pada perhitungan semua Peserta didik sudah tuntas dari nilai KKM yang telah ditentukan.

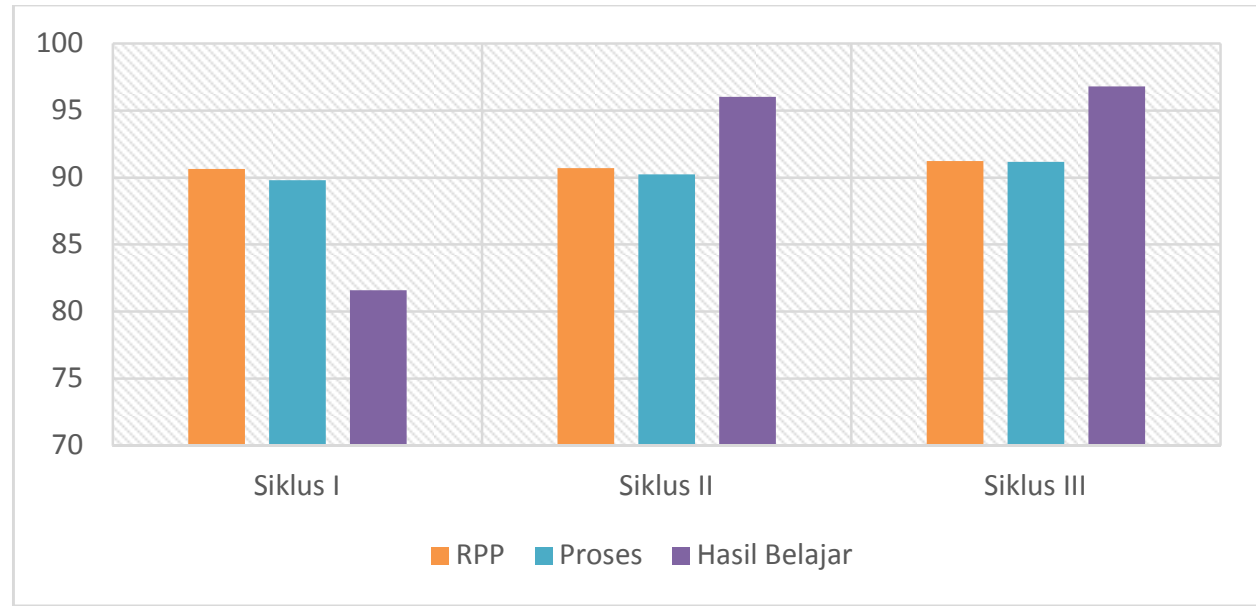

Hasil Pembelajaran Siklus I sampai Siklus III

Hasil penelitian tersebut membuktikan validitas sejumlah teori tentang lecture vary. Menurut W. Gulo metode lectures vary terdiri dari dua kata, yaitu lectures dan vary. Lectures adalah ceramah. Ceramah dapat diartikan sebagai cara menyajikan pelajaran melalui penuturan lisan atau penjelasan langsung kepada sekelompok peserta didik. Adapun vary artinya variasi. Metode lectures vary merupakan penggabungan antara metode ceramah, tanya jawab, penugasan dan yang lainnya, penggunaannya harus didukung dengan alat dan media atau dengan metode lainnya yang dapat menciptakan interaksi belajarmengajar yang dinamis dan bervariasi (Gulo, 2002, pp. 29-30).

Menurut W. Gulo disebut lectures vary karena dalam strategi ini terdapat beberapa komponen yaitu; 1) variasi metode ceramah; 2) variasi media alat indera; 3) variasi penampilan; 4) variasi bahan sajian (Gulo, 2002, p. 29). Adapun kelebihan dan kekurangan metode lectures vary menurut Hisyam Zaini sebagai berikut. Kelebihan metode lectures vary; 1) praktis dari sisi persiapan dan media yang digunakan; 2) efisiensi dari sisi waktu dan biaya; 3) dapat menyampaikan materi yang banyak; 4) mendorong guru atau dosen menguasai materi; 5) lebih mudah mengontrol kelas; 6) peserta didik tidak perlu persiapan; 7) peserta didik dapat langsung menerima ilmu pengetahuan. Sedangkan kekurangan metode pembelajaran lectures vary yaitu sebagai berikut; 1) membosankan; 2) informasi hanya satu arah; 3) menggurui dan 
melelahkan; 4) kurang terkendali baik waktu maupun materi (Hisyam \& dkk., 2008, p. 93).

Mengikuti langkah-langkah pembelajaran metode lecture vary, penelitian ini membuktikan kesahihan langkah-langkah penggunaan metode Lectures Vary, yang terdiri atas: Pertama, pendahuluan atau apersepsi; kedua, penjelasan atau menyajikan materi. Langkah penyajian adalah langkah penyampaian materi pelajaran sesuai dengan persiapan yang telah dilakukan. Yang harus dipikirkan guru dalam penyajian ini adalah bagaimana agar materi pelajaran dapat dengan mudah ditangkap dan dipahami oleh peserta didik. Karena itu ada beberapa hal yang harus diperhatikan dalam pelaksanaan langkah ini, yaitu sebagai berikut; a) penggunaan bahasa; b) intonasi suara; c) menjaga kontak mata dengan peserta didik; d) menggunakan variasi yang menyenangkan (Hisyam \& dkk., 2008, pp. 107-112).

Hasil belajar adalah kemampuan yang diperoleh anak setelah melalui kegiatan belajar. Belajar itu sendiri merupakan suatu proses dari seseorang yang berusaha untuk memperoleh suatu bentuk perubahan perilaku yang relatif menetap. Dalam kegiatan pembelajaran atau kegiatan intruksional, biasanya guru menetapkan tujuan belajar. Peserta didik yang berhasil dalam belajar adalah yang berhasil mencapai tujuan-tujuan pembelajaran atau tujuan intruksional (Jihad \& Haris, 2013, p. 14).

Menurut Benjamin S. Bloom dalam (Winkel, 1987, p. 149) tiga ranah (domain) hasil belajar, yaitu kognitif, afektif dan psikomotorik. Sementara menurut A.J. Romizowski seperti dikutip Jihad dan Haris, hasil belajar merupakan keluaran (outputs) dari suatu sistem pemrosesan masukan (input). Masukan dari sistem tersebut berupa bermacam-macam informasi sedangkan keluarannya adalah perbuatan atau kinerja (performance) (Jihad \& Haris, 2013, p. 14). Dapat disimpulkan bahwa hasil belajar merupakan pencapaian bentuk perubahan perilaku yang cenderung menetap meliputi ranah kognitif, afektif dan psikomotorik. Perubahan tersebut terjadi setelah proses belajar yang dilakukan dalam waktu tertentu.

Benjamin S. Bloom dalam (Jihad \& Haris, 2013, pp. 14-15) berpendapat bahwa hasil belajar dapat dikelompokkan ke dalam dua macam yaitu pengetahuan dan keterampilan. Pengetahuan terdiri dari empat kategori, yaitu: 1) Pengetahuan tentang fakta, 2) Pengetahuan tentang prosedural, 3) Pengetahuan tentang konsep, 4) Pengetahuan tentang prinsip. Keterampilan juga terdiri dari empat kategori, yaitu: 1) Keterampilan untuk berpikir atau keterampilan kognitif, 2) Keterampilan untuk bertindak atau keterampilan motorik, 3) Keterampilan bereaksi atau bersikap, 4) Keterampilan berinteraksi.

Untuk memperoleh hasil belajar, dilakukan evaluasi atau penilaian yang merupakan tindak lanjut atau cara untuk mengukur tingkat penguasaan Peserta 
didik. Kemajuan prestasi belajar peserta didik tidak saja diukur dari tingkat penguasaan ilmu pengetahuan tetapi juga sikap dan keterampilan. Dengan demikian penilaian hasil belajar Peserta didik mencakup segala hal yang dipelajari di sekolah, baik itu menyangkut pengetahuan, sikap, dan keterampilan (Jihad \& Haris, 2013, pp. 14-15). Adapun penilaian dalam proses pembelajaran meliputi: 1) evaluasi formatif, 2) evaluasi sumatif, 3) pelaporan hasil penilaian, 4) pelaksanaan program perbaikan atau pengayaan (Suryosubroto, 2002, p. 53).

Berdasarkan pendapat di atas dapat dijelaskan sebagai berikut: 1) evaluasi formatif adalah penilaian yang dilakukan guru setelah satu pokok bahasan selesai dipelajari oleh Peserta didik. Penilaian formatif disebutkan dengan istilah penilaian pada akhir satu pelajaran. Penilaian ini berfungsi untuk mengetahui sejauh mana ketercapaian tujuan intruksional khusus yang telah ditentukan dalam standar kompetensi; 2) evaluasi sumatif adalah penilaian yang diselenggarakan oleh guru setelah satu jangka waktu tertentu. Penilaian sumatif berguna untuk memperoleh informasi tentang keberhasilan belajar Peserta didik yang dipakai sebagai masukan utama untuk menentukan nilai lapor atau nilai akhir semester; 3) pelaporan hasil penilaian. Setelah memberikan evaluasi formatif maupun sumatif, setiap tengah semester atau akhir semester guru harus mengolah nilai akhir dan memasukan dalam buku lapor, yang merupakan laporan hasil kerja. Buku lapor berfungsi untuk laporan hasil kerja sekolah kepada orang tua atau wali murid; 4) pelaksanaan program perbaikan dan pengayaan. Apabila seorang peserta didik dalam ulangan (tes formatif atau tes sumatif) mencapai nilai kurang dari 6,00 atau daya serapnya kurang dari $60 \%$ maka yang bersangkutan harus mengikuti perbaikan. Tujuan ulangan perbaikan adalah agar Peserta didik memperoleh penguasaan yang baik terhadap tujuan pembelajaran yang harus dicapai, dengan menjelaskan materi yang sedang dipelajari atau memberikan tugas tambahan kepada Peserta didik yaitu mengerjakan kembali soal. Bagi Peserta didik yang sudah mencapai standar kompetensi, sekurang-kurangnya 60\% dapat diberikan pengayaan, apabila masih ada waktu untuk satu pelajaran tertentu sebelum beralih kepada materi lain.

Kehadiran faktor-faktor psikologis dalam belajar akan memberikan andil yang cukup penting. Faktor-faktor psikologis akan senantiasa memberikan landasan dan kemudahan dalam upaya mencapai tujan belajar secara optimal. Sebaliknya, tanpa kehadiran faktor-faktor psikologis, bisa jadi memperlambat proses belajar, bahkan dapat pula menambah kesulitan dalam belajar (Djamarah, 2008, p. 58). Faktor psikologis pada umumnya meliputi kemampuan, motivasi (motif) belajar, minat dan perhatian, sikap dan 
kebiasaan, bakat khusus dan kesiapan belajar, sedangkan faktor fisiologis adalah kondisi fisik Peserta didik itu sendiri.

Metode adalah cara yang digunakan guru untuk mengimplementasikan rencana pembelajaran yang sudah disusun dalam kegiatan nyata agar tujuan yang diinginkan tercapai secara optimal. Ini berarti metode digunakan untuk merealisasikan strategi yang telah ditetapkan sehingga dapat dikatakan bahwa metode dalam rangkaian sistem pembelajaran memegang peranan yang sangat penting. Hal ini sesuai dengan pendapat Sanjaya yang menyatakan bahwa keberhasilan implementasi strategi pembelajaran sangat tergantung pada cara guru menggunakan metode pembelajaran, karena suatu strategi pembelajaran hanya mungkin dapat diimplementasikan melalui penggunaan metode pembelajaran (Sina, 2011, p. 6).

Metode yang dilakukan guru dapat mengakibatkan penyajian bahwa pelajaran lebih menarik perhatian Peserta didik, mudah diterima atau dipahami Peserta didik dan kelas pun menjadi lebih hidup. Dengan demikian, jelas bahwa penggunaan metode sangat mempengaruhi proses belajar mengajar di kelas sehingga dapat meningkatkan perkembangan hasil belajar Peserta didik. Maka dapat disimpulkan bahwa faktor-faktor yang mempengaruhi hasil belajar salah satunya yaitu penggunaan metode dalam pembelajaran, dengan menggunakan metode pembelajaran dapat membangkitkan keinginan dan minat yang baru, membangkitkan motivasi dan rangsangan kegiatan belajar, membawa pengaruh-pengaruh psikologis terhadap Peserta didik, dan akhirnya akan membuahkan hasil belajar yang baik. Adapun faktor luar yang mempengaruhi terhadap proses dan hasil belajar meliputi faktor lingkungan, lingkungan sosial dan lingkungan alam. Kemudian juga faktor instrumen yang meliputi bahan pengajaran termasuk kurikulum, guruatau pengajar, media dan teknik mengajar, sarana dan fasilitas belajar.

Kesimpulan

Berdasarkan hasil penelitian yang telah dideskripsikan pada pembahasan sebelumnya, bahwa hasil belajar Peserta didik pada mata pelajaran Aqidah Akhlak pokok bahasan 'menghindari akhlak tercela' pada peserta didik kelas V MI Kiarapayung Kecamatan Rancah Kabupaten Ciamis, dengan berbagai upaya dan tindakan telah mengalami peningkatan dari siklus I sampai pada siklus III, untuk itu dapat diambil kesimpulan sebagai berikut:

Pertama, perencanaan pembelajaran Aqidah Akhlak pokok bahasan 'menghindari akhlak tercela' menggunakan metode lectures vary di kelas V MI Kiarapayung Kecamatan Rancah Kabupaten Ciamis yang dilakukan oleh guru telah sesuai dengan acuan standar KTSP, dan mengalami peningkatan setiap 
siklusnya. Hal ini dapat dilihat dari hasil observasi perencanaan pembelajaran pada Siklus I mencapai nilai rata-rata 90,65 (baik) sedangkan pada Siklus II mencapai nilai rata-rata 90,69 (baik) dan pada Siklus III mencapai nilai ratarata 91,23 (sangat baik). Kedua, pelaksanaan pembelajaran Aqidah Akhlak pokok bahasan 'menghindari akhlak tercela' dengan menggunakan metode pembelajaran lectures vary di kelas V MI Kiarapayung Kecamatan Rancah Kabupaten Ciamis yang dilakukan oleh guru telah menunjukkan kegiatan pembelajaran yang mengacu pada pembelajaran aktif, inovatif, kreatif, efektif, dan menyenangkan. Kemampuan guru dalam melaksanakan pembelajaran terus mengalami peningkatan dari siklus ke siklus. Hal tersebut dapat dilihat dari hasil observasi pada Siklus I kemampuan guru mencapai 89,81(baik) sedangkan pada Siklus II mencapai nilai rata-rata 90,22 (baik) dan pada Siklus III mencapai nilai rata-rata 91,16 (sangat baik). Ketiga, Hasil belajar peserta didik kelas V MI Kiarapayung Kecamatan Rancah Kabupaten Ciamis setelah mengikuti pembelajaran Aqidah Akhlak pokok bahasan 'menghindari akhlak tercela' mengalami peningkatan dari siklus ke siklus. Hal itu dapat dilihat dari nilai tes pada Siklus I mencapai nilai rata-rata 81,6 (baik) dengan presentase ketuntasan 72\% sedangkan pada Siklus II mencapai nilai rata-rata 96 (baik) dengan presentase ketuntasan $96 \%$ dan pada Siklus III mencapai nilai rata-rata 96,8 (baik) dengan presentase ketuntasan 100\%.

\section{DAFTAR PUSTAKA}

Al-Ghazali, A. H. (1970). Khuluq Al Muslim. Kuwait: Dar Al- Bayan.

Amin, A. (1993). Etika: Ilmu Akhlak. Jakarta: Bulan Bintang.

Azzam, A. (1993). Akidah Landasan Pokok Membina Umat. Jakarta: Gema Insani Press.

Djamarah, S. B. (2008). Psikologi Belajar. Jakarta: Rineka Cipta.

Gulo, W. (2002). Strategi Belajar Mengajar. Jakarta: PT. Grasindo.

Halim, M. N. A. (2000). Menghias Diri dengan Akhlak Terpuji. Yogyakarta: Mitra Pustaka.

Heruman. (2010). Model Pembelajaran Matematika di Sekolah Dasar. Bandung: PT. Remaja Rosdakarya.

Hisyam, Z., \& dkk. (2008). Strategi Pembelajaran Aktif. Yogyakarta: Pustaka Insan Madani.

Jihad, A., \& Haris, A. (2013). Evaluasi Pembelajaran. Yogyakarta: Multi Pressindo.

Mahmud. (2011). Pemikiran Pendidikan Islam. Bandung: CV. Pustaka Setia.

Mufarokah, A. (2009). Strategi Belajar Mengajar. Yogyakarta: Teras.

Nurhayati. (2014). Akhlak dan Hubungannya dengan Aqidah dalam Islam. 
Jurnal MUDARRISUNA: Media Kajian Pendidikan Agama Islam, 4(2), 289-309.

Sina, I. (2011). Implementasi Model Pembelajaran Role Playing Berbasis Analisis SWOT Pada Materi Peluang: Penelitian Tindakan Kelas Pada Siswa Kelas XI SMAN 1 Wanasari. Cakrawala: Jurnal Pendidikan, 6(1), 0-8. Retrieved from http://ejournal.upstegal.ac.id/index.php/Cakrawala/article/view/69/78

Sudjana, N. (2004). Dasar-dasar Proses Belajar Mengajar. Bandung: Sinar Baru. Suryosubroto. (2002). Proses Belajar Mengajar di Sekolah. Jakarta: Rineka Cipta.

Suyoto, S. (2016). Pengembangan Penelitian Pendidikan Agama Islam Bagi Pengawas: Model Penelitian Tindakan di Sekolah dan Kelas (Studi Kasus di Kabupaten Trenggalek). Ta'allum: Jurnal Pendidikan Islam, 4(2), 371396. https://doi.org/10.21274/taalum.2016.4.2.371-396

Wardati. (2011). Implementasi Bimbingan Dan Konseling Di Sekolah. Jakarta: Prestasi Pustakarya.

Winkel, W. S. (1987). Psikologi Pengajaran. Jakarta: Gramedia.

Wiraatmaja, R. (2008). Metode Penelitian Tindakan Kelas. Bandung: PT. Remaja Rosdakarya.

Yunus, M. (1973). Kamus Arab Indonesia. Jakarta: Hidayah Karya Agung. 